\title{
Geologic mapping and environmental analyses in the vicinity of the damaged red sludge reservoir at Kolontár
}

\author{
István Marsi, Ildikó Selmeczi, \\ László Koloszár, József Vatai, \\ Ildikó Szentpétery, \\ Geological and Geophysical Institute of Hungary
}

\author{
Árpád Magyari \\ MOL Hungarian Oil and Gas PLC
}

László Róth

The authors carried out geologic investigations in the Kolontár area in connection with the red mud catastrophe of 4 October 2010, and have acquired more detailed knowledge using geologic mapping methods. This study is an evaluation on the basis of the immediate analyses that were made after the accident and are published in this paper.

Based on their research results the authors find that the alluvial deposits of the Torna Brook are highly inhomogeneous, which is manifested in the variability of stability and bearing capacity. Based on the morphology in the area of Kolontár a small, rhombus-shaped pull-apart basin can be outlined, which can be interpreted as a neotectonic event characterized by a right-lateral fault. However, further detailed research is needed in order to understand what kind of role the geologic environment played in the development of the situation that led to the dam failure.

Key words: red mud, Kolontár, Hungary, landform description, Quaternary, Middle Miocene, neotectonics, DEM

Addresses: I. Marsi, I. Selmeczi, L. Koloszár, J. Vatai, I. Szentpétery: H-1143 Budapest, Stefánia út 14, Hungary, e-mails: marsi.istvan@mfgi.hu; selmeczi.ildiko@mfgi.hu; koloszar.laszlo@mfgi.hu; vatai.jozsef@mfgi.hu; szentpetery.ildiko@mfgi.hu Á. Magyari: H-1117 Budapest, Október 23.u. 18, e-mail: a.magyari@mol.hu L. Róth: H-1122 Budapest, Hajnóczy J. u. 4, e-mail: roth@geol.hu

Received: November 18, 2011; accepted: April 24, 2013 


\section{Introduction}

Our research work was carried out in November 2010 and in the spring of 2011. In the course of our studies our main goal was to carry out immediate and detailed geologic examinations (i.e. the interpretation of remote sensing data and DEM, as well as field investigations including paleontological studies as well as granulometric and carbonate content measurements) in order to acquire more detailed geologic knowledge. These may provide a basis for investigating the geologic causes of the catastrophe (Fig. 1) and may help the engineering design in order to avoid environmental problems.

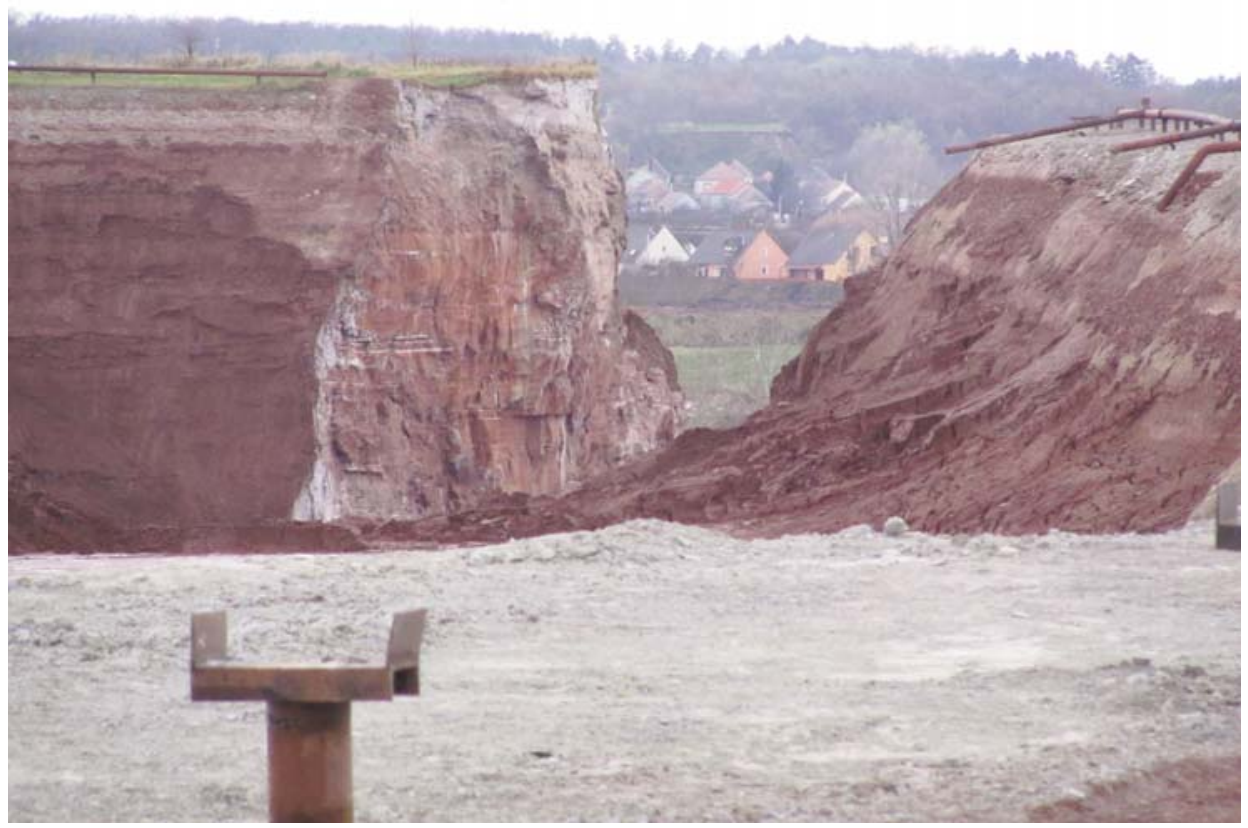

Fig. 1

The collapsed dam

\section{Previous investigations}

Geologic mapping

Detailed geologic mapping of the Kolontár-Devecser area (Fig. 2) began in the middle of the last century. The first data were published by Kovács $(1948,1952)$ and Darnay-Dornyai (1952).

In the 1960s and 1970s the Geological Institute of Hungary carried out the geologic mapping of the Southern Bakony on a scale of 1:10 000. In the course of 


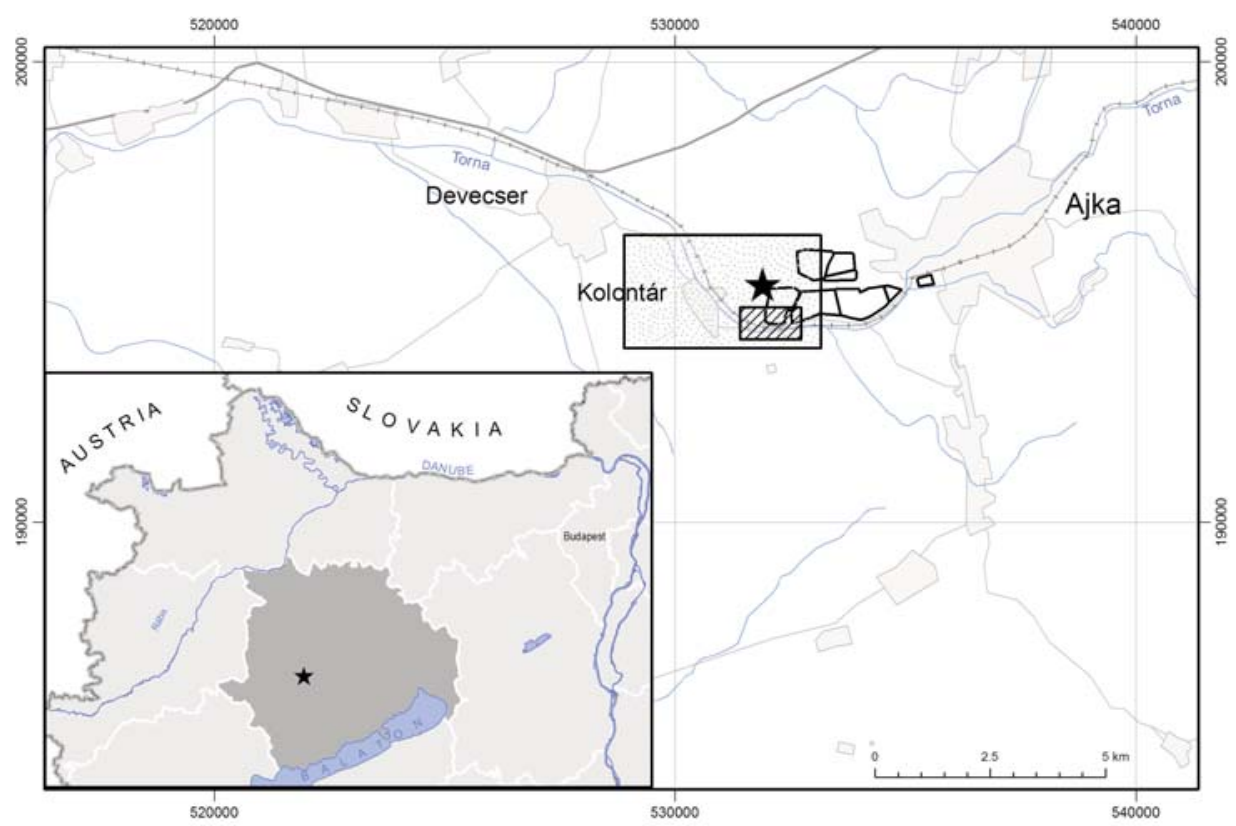

Fig. 2

Location of the study area with the larger settlements

The research area is marked with dots; oblique hachures designate the area shown in Fig. 6.

this work several boreholes were drilled in the area. The results were published in the form of geologic maps (i.e. geologic maps of the Quaternary cover and bedrock geology maps) at a scale of 1: 20000 (Fig. 3) and in the explanatory books to these maps (note that the area shown in Fig. 3 is smaller than the $4 \mathrm{~km} \times 4 \mathrm{~km}$ sized area of the geologic reambulation. The legend comprises the original numbers; thus numbering is not continuous).

The area studied by the authors is located at the point of contact of four geologic maps at a scale of 1:20 000, of which three have already been published. These are the following: Ajka (Mészáros 1976a, b, 1979), Devecser (Bihari 1979a, b, 1983), and Padragkút (Mészáros 1976c, d, 1980). The geologic maps of the Quaternary cover and of the bedrock geology of the "Nyirád" sheet are available only in manuscript forms (Csima 1975a, b; Csima et al. 1975).

The geologic maps of the Bakony Mountains (at a scale of 1:50 000) were compiled on the basis of data gained from the geologic mapping and from the reambulation work in certain areas (Császár et al. (eds.) 1985; Gyalog and Császár (eds.) 1990; explanatory book to the maps: Bence et al. 1990). Pre-Quaternary formations are already classified into lithostratigraphic units on these maps, whereas Quaternary formations are classified on the basis of genetics. 
Several data have been published in connection with the tectonic features of the wider surroundings of the study area [e.g. Mészáros $(1982,1983)$, Dudko et al. (1992)].

\section{Geophysical measurements}

Geophysical measurements were carried out predominantly in connection with bauxite research and Upper Cretaceous coal research. Since the 1950s repeated gravity, geoelectric and seismic refraction measurements have been performed. The results were published by, among others, Hoffer and Nyitrai (1984), and Ráner (1973).

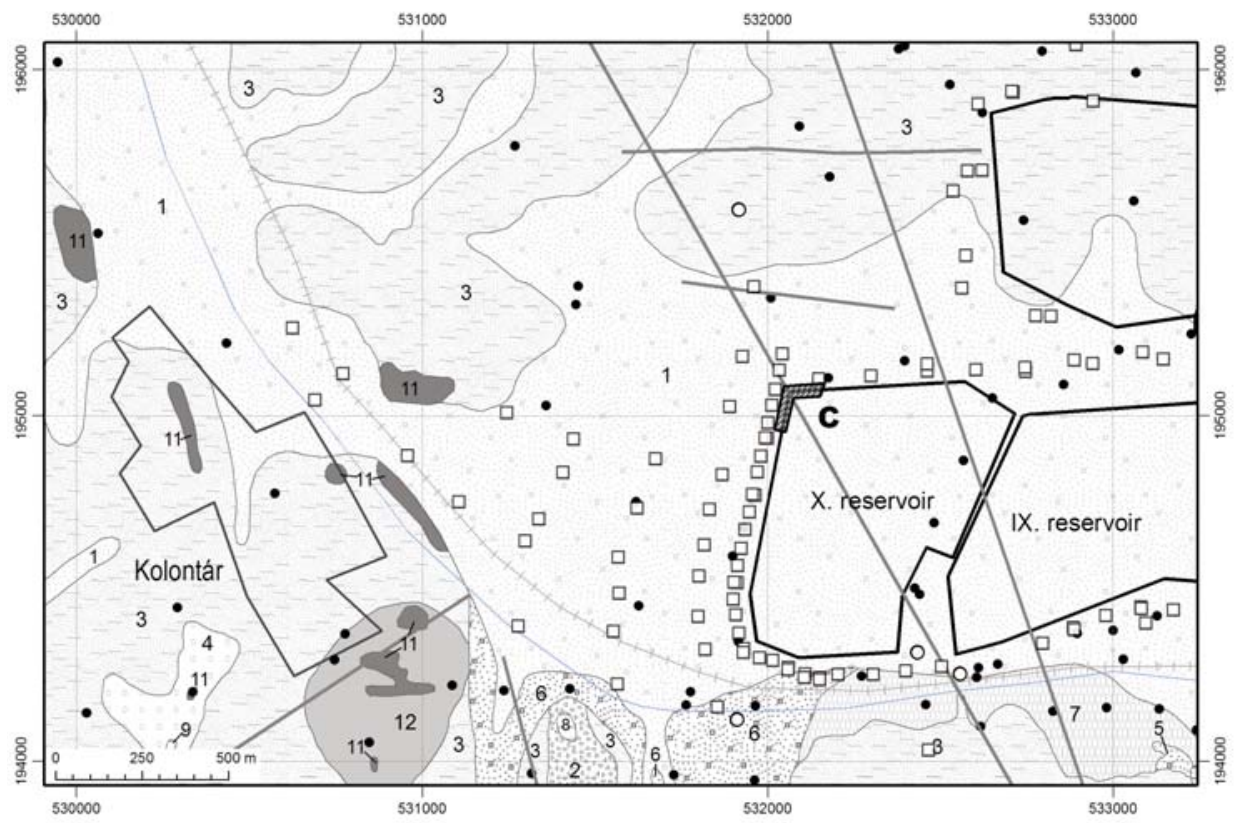

Fig. 3

Archive map based on the geologic map series of the Bakony Mountains at a scale of 1: 20 000, geologic map of the Quaternary cover and bedrock geology map. Digital elaboration: Sz. Nagy and Zs. Vikor Legend: Holocene: 1. fQ_h fluvial sediments, Upper Pleistocene-Holocene 2. p_Qp3-h_h proluvial sand, 3. d Qp3-h k deluvial gravel, sandy gravel, 4. eld Qp3-h k eluvial-deluvial gravel, Upper Pleistocene: 5. f_Qp3 fluvial sediments, 6. f_Qp3_k,h fluvial gravel and sand, 7. e_Qp3-1 loess, Miocene and Holocene: 8. tM2 + f Qh1 k Tinnye Formation and fluvial gravel together, Miocene 9. 1M2 Lajta Formation, Miocene and Holocene together, Miocene 11 and 12. pmM2_k,h Pusztamiske Formation: gravel and sand (in situ and in debris). Archive research objects: $\bullet$ site of geophysical measurement, $\square$ location of monitoring well, $\bigcirc$ location of previous borehole, - track of geophysical measurement 


\section{Pedological mapping}

The study area is located in the Devecser sheet No. 5159/3 of the pedological mapping project at a scale of 1: 25000 that was initiated by Kreybig. According to the data on this map there are lime-rich or neutral and slightly acidic soils (characterized by conditional lime requirement); these soils are of good waterabsorbing capacity and transmissibility in the area of Kolontár (Kléh, undated).

The eastern border of the complex geologic mapping of the Kisalföld (Little Hungarian Plain) - at a scale of 1: 100000 - coincided with the border of Kolontár (Síkhegyi 1984). Data obtained from the laboratory analyses of samples which had been taken from surface and near-surface layers, soil and groundwater of the wider vicinity within the framework of this study can be considered as a control series for the investigations of environmental changes following the disaster.

\section{Geologic background}

Considering the basement morphology the Devecser-Kolontár sedimentary basin can be well identified in the area of the Transdanubian Range. The basement and the margins of the basin are made up of Mesozoic (Triassic and Cretaceous), Eocene and Oligocene rocks. The tectonic movements that took place during the Karpatian and Lower Badenian resulted in subsidence and the sea invaded the area (Selmeczi 2003). The greatest subsidence took place during the younger phase of the Early Badenian, and it was most intensive SSW of the study area, in the vicinity of Pusztamiske (Pusztamiske Depression).

The Oligocene-Lower Miocene terrestrial successions are overlain by Lower Badenian beds of large areal extent; they can be found both on the surface and in the subsurface. The Lower Badenian succession is made up of marine and brackish-water sediments. Marine sediments are represented by the Leithakalk (Lajta Formation, Pécsszabolcs Member) and the Pusztamiske Formation. Their beds reflect different sedimentary facies which were in close connection with each other; their layers interfinger with each other. The main rock types of Leithakalk (from the margins toward the open sea) are the following: calcareous conglomerate/pebbly limestone, sandy limestone, calcarenite and molluskbearing corallinacean limestone.

In some thin sections of limestone corallinacean algae, foraminifers, mollusks and fragments of echinoderms can be seen (Fig. 4a). The limestone in Exposure KD-4 contained the foraminifer species Planostegina giganteoformis (Papp) (Fig. 4b). The formation crops out on the southwestern side of the road from Kolontár to Devecser, and on the Tik-hegy (Tik Hill). It is several tens of meters thick. In the wider area it transgresses onto the Oligocene-Lower Miocene terrestrial formations (in the vicinity of Nyirád onto the Mesozoic basement), or at its lower boundary it forms a continuous transition from the underlying Pusztamiske Formation.

In Kolontár the Pusztamiske Formation is represented by abrasional conglomerate beds on the surface (Kolontár Member), which dip southeastward 

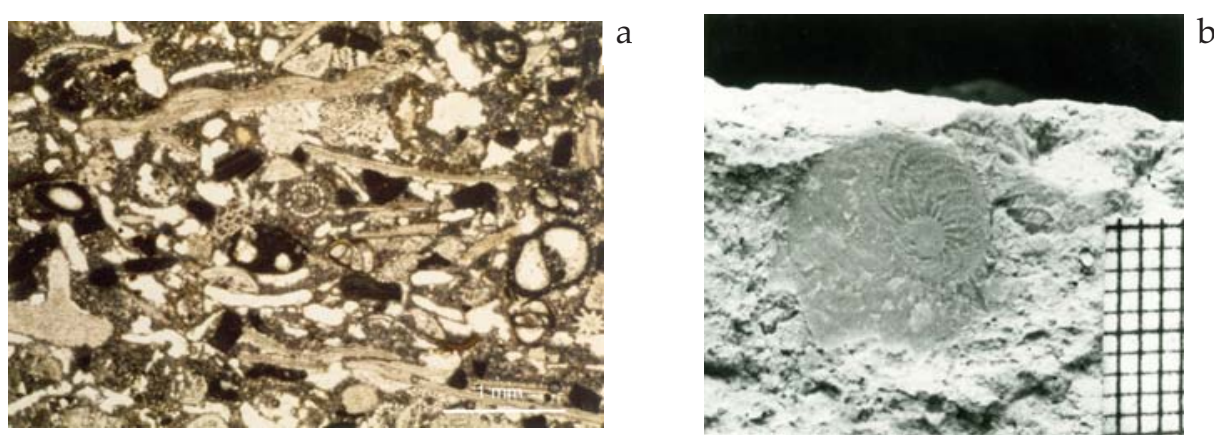

Fig. 4

a) Corallinacean limestone: corallinacean algae, foraminifers, mollusk and echinoderm fragments (Exposure KD-3, SE of Devecser. Photo: Gy. Lelkes)

b) Planostegina giganteoformis (Papp) (Exposure KD-4, $700 \mathrm{~m}$ to the E of Devecser). Scale in $\mathrm{mm}$

at angles between $13^{\circ}$ and $20^{\circ}$. Pebbles have been redeposited from older (Oligocene and Lower Miocene terrestrial) pebbly successions occurring in the area; compared to the older fluvial successions the Kolontár Member comprises more mature pebbles, with a predominance of quartzite, quartz and metamorphic pebbles; the proportion of Eocene and Mesozoic limestone pebbles and Permian sandstone pebbles is much lower. Its marine deposition is indicated by the presence of the Ostrea-Anomia-Balanus mollusk assemblage characteristic of near-shore facies (Selmeczi 2003) in the now abandoned gravel pits in Kolontár.

In the wider vicinity of Kolontár Middle Miocene sediments younger than Early Badenian [i.e. Hidas Formation / Meggyeserdő Member (Middle and Upper Badenian), Kozárd, Tinnye and Gyulafirátót Formations (Sarmatian)], can also be found (Fig. 5). The Upper Miocene (Pannonian) is represented by the Kisbér and Szák Formations SW of the study area, whereas in the surroundings of AjkaPadragkút, sediments belonging to the Somló and Kálla Formations are found.

Older (Mesozoic and Paleogene) formations crop out at surface in the neighborhood, and large areas are covered with Quaternary deposits of varying facies.

\section{Methodology}

Remote sensing data

In the course of the preparatory work for field observations we used true color composite image series at a scale of 1: 10 000, of 1985 vintage (Fig. 6).

\section{$D E M$}

A Digital Elevation Model (DEM) at $5 \mathrm{~m} \times 5 \mathrm{~m}$ resolution was used. For aerial photos we used visible-spectrum images made by the Károly Róbert College following the environmental disaster. A map covering a $23 \mathrm{~km} \times 10 \mathrm{~km}$-large area 


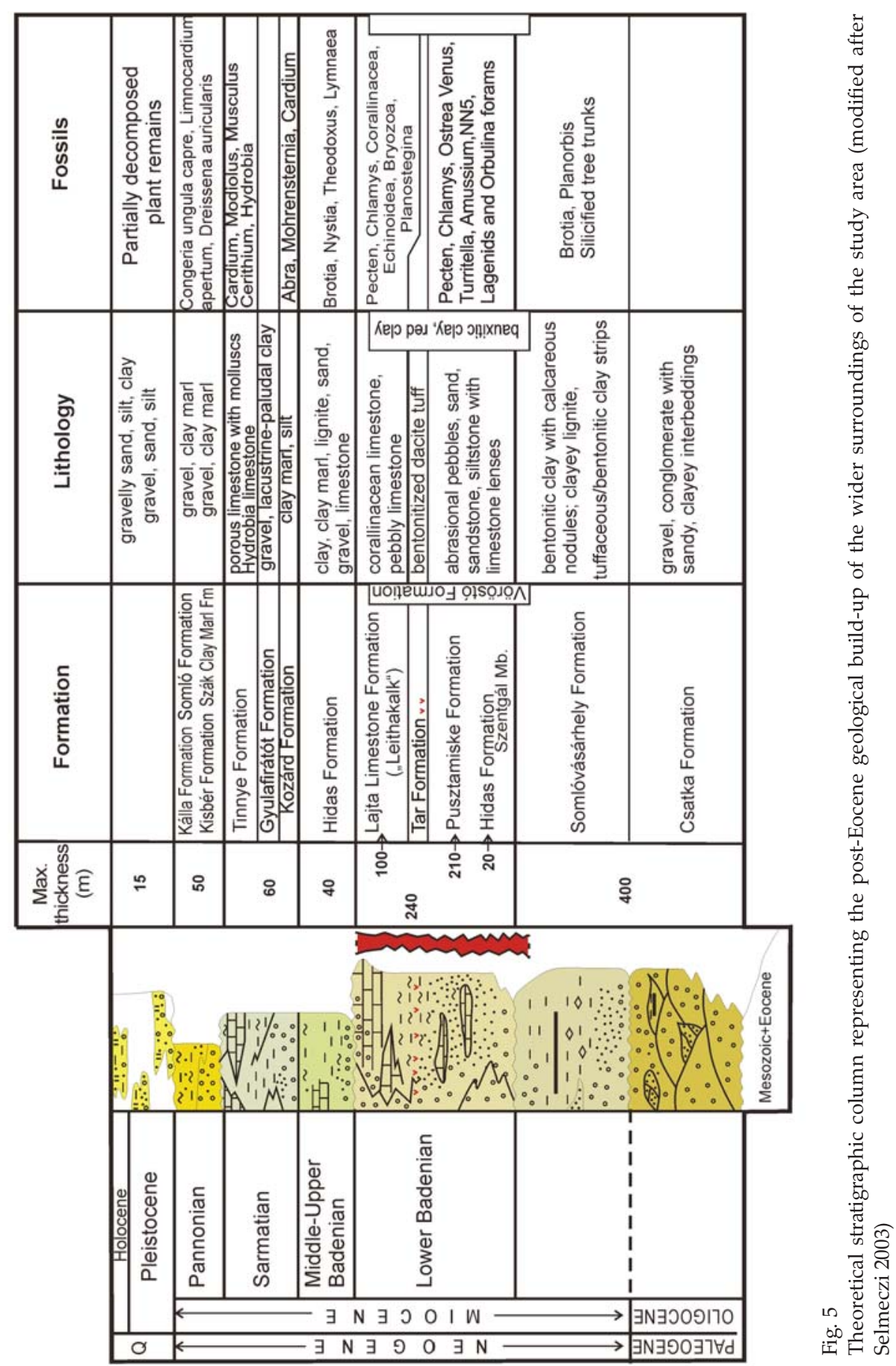

Central European Geology 55, 2012 


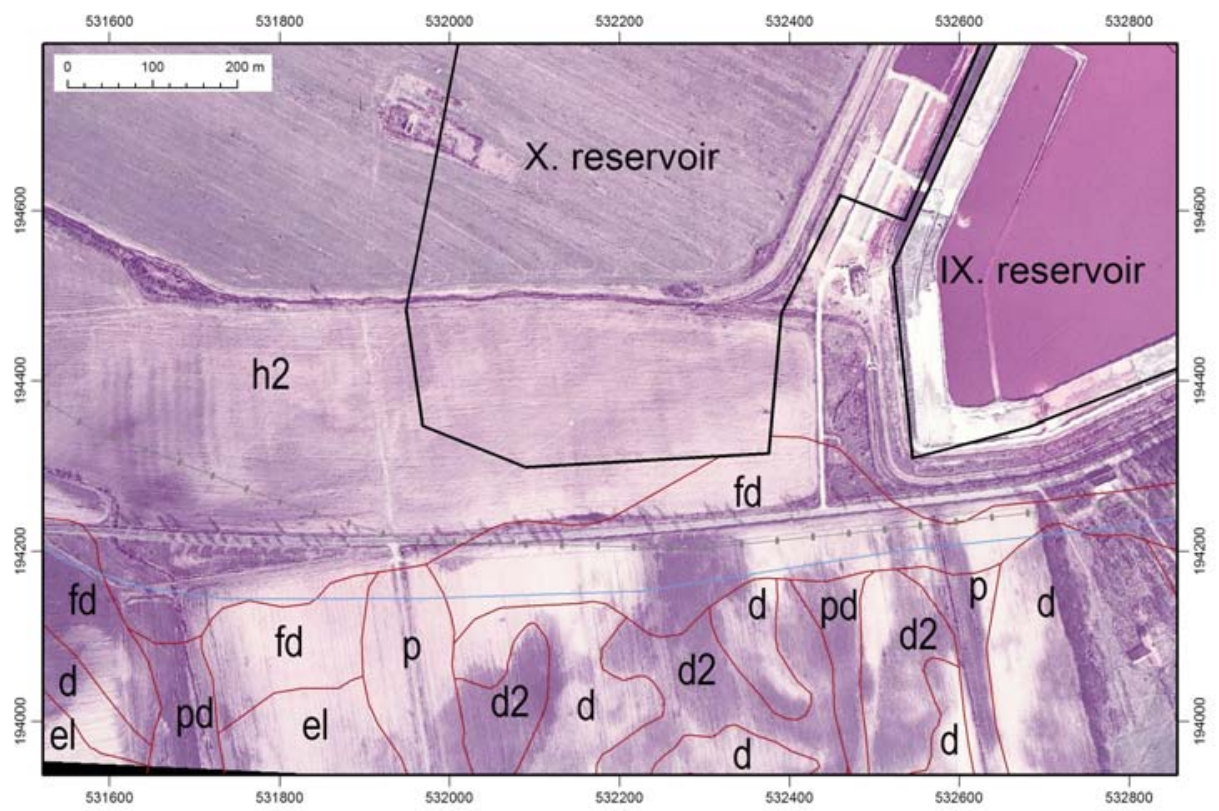

Fig. 6

Manually processed aerial photograph showing the area at a scale of 1: 10000 , color-accurate series. Legend: el = eluvial sediments; $\mathrm{d}=$ old deluvial sediments; $\mathrm{d} 2=$ young deluvial sediments; $\mathrm{fd}=$ fluvial-deluvial sediments; $\mathrm{h} 2$ = lower flood-plain; $\mathrm{p}=$ proluvial sediments; $\mathrm{pd}=$ proluvial-deluvial sediments

and with a resolution of $5 \mathrm{~m} \times 5 \mathrm{~m}$ was available and used for terrain modeling. In order to carry out investigations in the immediate surroundings a cut-out map representing a $5 \mathrm{~km} \times 5 \mathrm{~km}$ area was prepared. We carried out investigations in order to mark the boundaries of the drainage basin and the catchment area. For drainage studies in the wider vicinity of the study area we used an elevation model at $10 \mathrm{~m} \times 10 \mathrm{~m}$ resolution. In the course of processing RiverTools and ENVI software were used.

\section{Field observations}

Preparatory work was followed by the process of field reambulation of an area of $4 \times 4 \mathrm{~km}^{2}$ at a scale of 1:10 000. This was carried out by Selmeczi, Koloszár and Marsi on 23-25 November 2010. As a result of this work the geologic field map and the geologic map of the Quaternary cover were completed (Fig. 7) (note that the area shown in Fig. 7 is smaller than the $4 \mathrm{~km} \times 4 \mathrm{~km}$-sized area of the geologic reambulation. The legend comprises the original numbers; thus numbering is not continuous). The work was supported by data derived from manual drilling (carried out by the Geological Institute of Hungary) and from excavated pits, the 
rock samples of which were subjected to laboratory (i.e. sedimentological and geochemical) tests. Results are already partly available. The previously planned deeper boreholes have not yet been drilled.

\section{Paleontological investigations}

Sütő-Szentai $(2010 \mathrm{a}, \mathrm{b})$ carried out sporomorph investigations from samples of sections from 4.8-6.0 m and 10.0-11.0 m of borehole Kolv-1 and from 8.0-9.0 m and 9.0-11.0 m of borehole Kolv-2. Szegó $(2010 \mathrm{a}, \mathrm{b})$ determined foraminiferal taxa from boreholes Kolv-1 (4.8-6.0 m and 10.0-11.0 m) and Kolv-2 (8.0-9.0 m and 9.0-10.0 m) and from Exposure KD-15 (research pit).

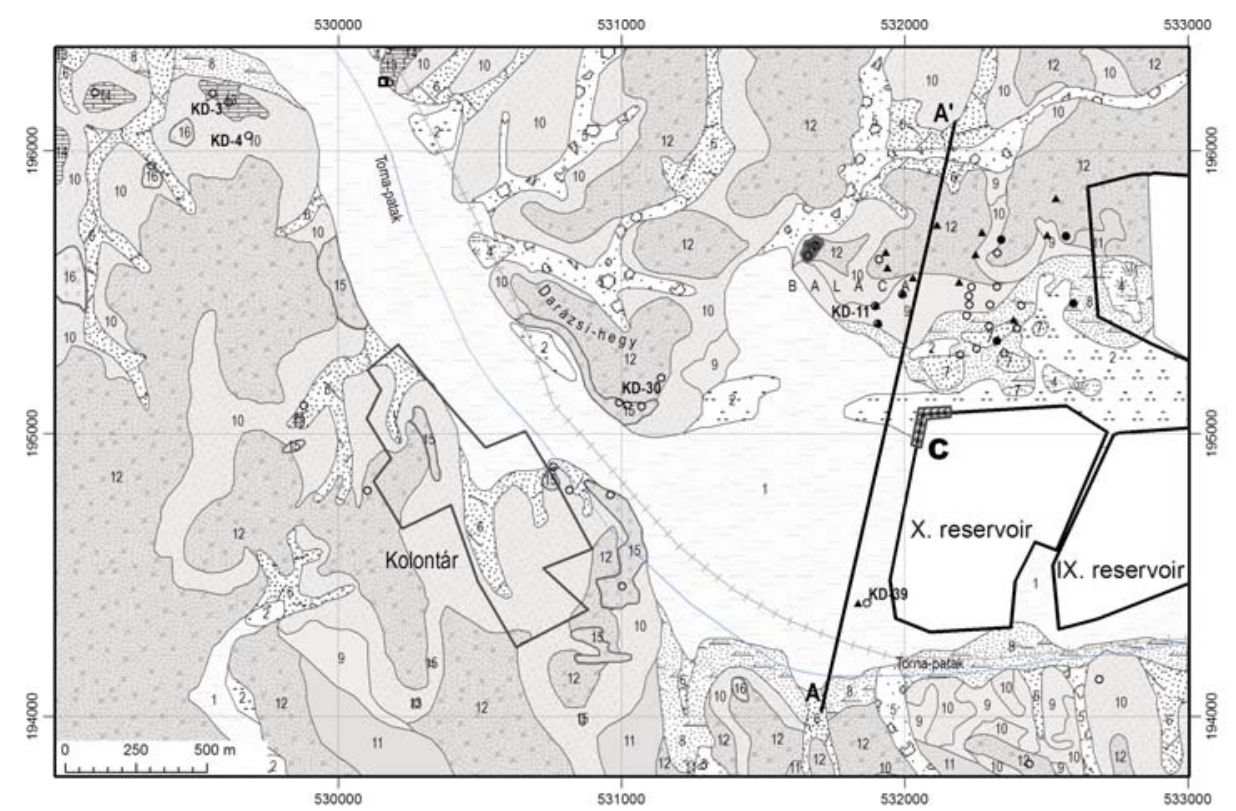

Fig. 7

Geologic map series of the vicinity of Kolontár, geologic map of the Quaternary cover and bedrock geology map, at a scale of 1:10 000, compiled by I. Marsi. Legend: 1 . fQ_h fluvial sediments (alluvium in general), 2. fb_Qh fluvial-paludal sediments; organic-rich sandy silt, silt, 3. fp_Qh fluvial-proluvial sediments; pebbly sand and silt. This formation is not present in the figure which represents only a detail of the geological map 4. b_Qh paludal sediments; organic-rich clay and silt, 5. p_Qh proluvial sediments; sand, gravel and silt, 6. pd_Qh proluvial-deluvial sediments, 7. f_Qh_kh fluvial bedload material; pebbly sand and silt, 8. fd_Qh fluvial-deluvial sediments, Upper Pleistocene-Holocene 9. d_Qp3-h fine-grained slope sediments; sand with scattered pebbles, silt 10. d_Qp3-h_k,h coarsegrained slope sediments; pebbly sand and rock debris. 11. eld_Qp fine-grained eluvial sediments (residual surfaces that underwent pedogenetic processes, sand with scattered pebbles, silt), 12 eld_Qp_k,h eluvial sediments (pebbly deflation residues), Miocene 13. 1_pM2 Lajta Formation Pécsszabolcs Member in situ, 14. 1 pM2 t Lajta Formation Pécsszabolcs Member in debris, 15. pm_kMb1 Pusztamiske Formation in situ, 16. pm_kMb1_t Pusztamiske Formation in debris, 17 h_szMb1 Hidas Formation Szentgál Member; $\bigcirc$ Location of the exposure, $\boldsymbol{\Delta}$ site of leakage measurement, $\bullet$ location of shallow drilling, A-A' track of shallow geologic cross-section 
Mollusks derived from exposures, research pits and the samples from manual drilling were determined by the authors.

\section{Granulometric composition and carbonate content measurements}

In the laboratory of the Geological Institute of Hungary granulometric composition and carbonate content measurements were carried out from material derived from the 4 manual drilling locations and 2 research pits located in the area, as well from samples from a clay pit near Devecser (Bartha 2010). Carbonate content was measured by several methods and within the total carbonate content the quantity of calcite and dolomite was separated.

These examinations served for the characterization of the granulometric composition, water transmissibility and water-retention capacity of the sediments of the Kolontár mapping area, especially for the planned provisional reservoir, and the survey of the spatial variability of the surface and near-surface formations. Carbonate content analyses permit the evaluation of carbonate content in the parent rock section, even in zones deeper than made possible by pedological analyses.

\section{Compilation of shallow sections}

The preliminary, shallow geologic cross-sections were compiled on the basis of the following data:

- records kept by the National Archive of the Hungarian Office for Mining and Geology concerning monitoring wells of a depth of 5-10 m (exceptionally $20 \mathrm{~m}$ ) which were drilled around the red mud reservoir of the MAL Zrt (Hungarian Aluminum Production and Trade Company Limited) and the fly ash reservoirs of the Bakonyi Hőerőmú (Bakony Power Plant Co. Ltd.)

- data derived from the succession of borehole Ajka At-8 drilled by the Geological Institute of Hungary in 1968

- data obtained from 4 shallow boreholes drilled by the Geological Institute of Hungary in November 2010

- petrologic information obtained from 22 research pits and sampling localities for leakage measurements.

\section{Results and Discussion}

Information gained from remote sensing data

The aerial photographs helped in distinguishing the fine-grained, clayey Miocene sediments (dark tones) from the pebbly ones (light tones), in distinguishing the eluvial and deluvial deposits of the Miocene formations as well as in the division of the alluvial plain and in the recognition of eroded and uneroded terrains. 


\section{$D E M$}

Information (shaded relief image, relief enhancement, defining the borders of secondary catchment areas, slope conditions) gained from the Digital Elevation Model (DEM) (Fig. 8) helped in the compiling of geologic maps and neotectonic interpretation.

Field observations and new paleontological data

Miocene formations

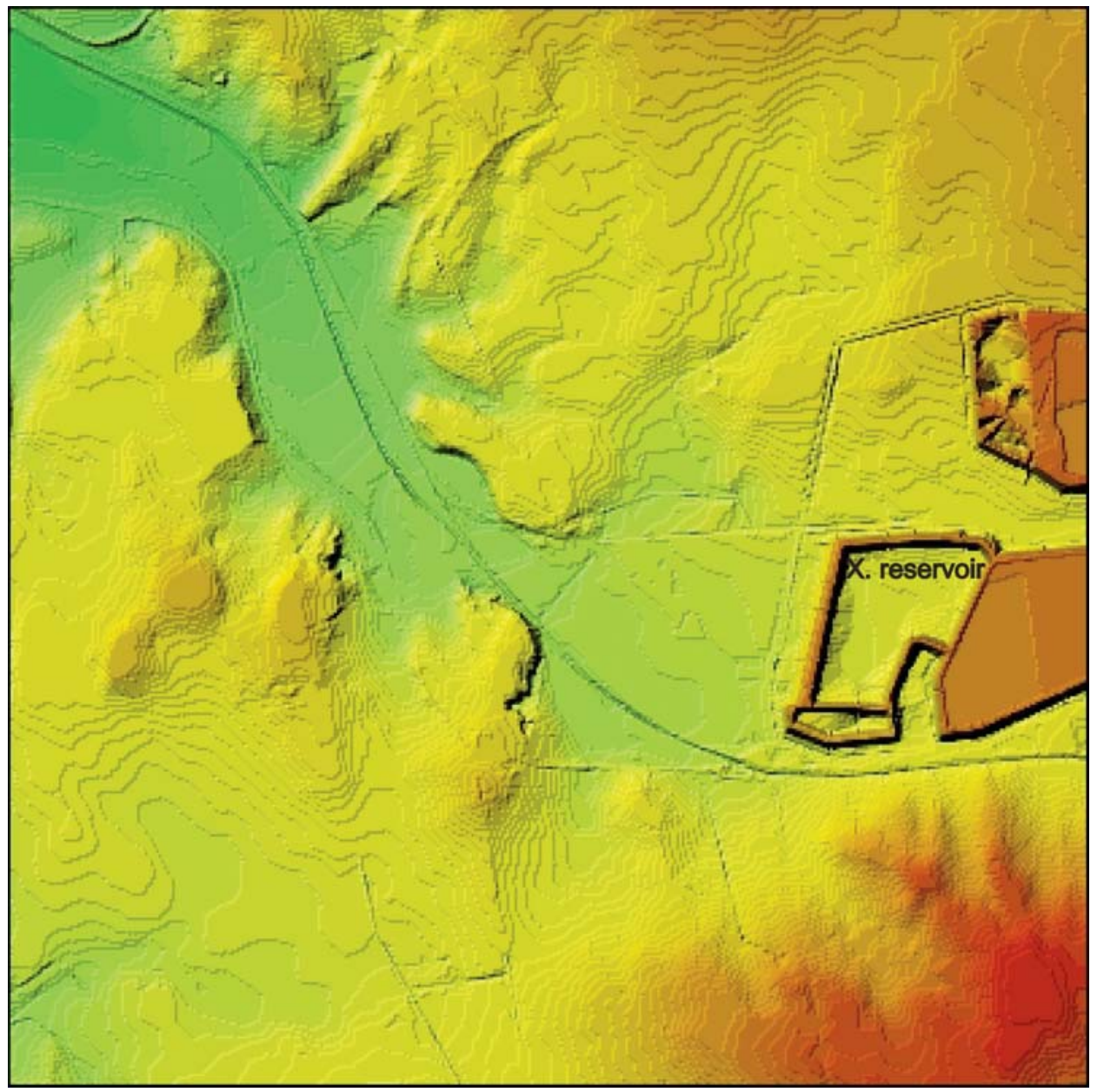

Fig. 8

Digital Elevation Model (DEM) compiled by L. Róth, file: ENVI Standard; pixel: $5 \mathrm{~m}$. Shaded relief: young alluvial valley - morphological levels cannot be distinguished 
As a result of geologic reambulation the authors have more accurately determined the surficial extent and characteristics of Middle and Upper Miocene sediments (Table 1) and classified the Quaternary deposits into facies groups (Table 2).

The facies variability of the Lower Badenian rocks reflects paleogeographic variability within a small area. On the basis of field observations, paleontological investigations and data derived from borehole successions, it can be presumed Table 1

Miocene formations identified in the study area

\begin{tabular}{|l|l|}
\hline \multirow{2}{*}{ Upper Miocene (Pannonian) } & Kálla Gravel Formation \\
\cline { 2 - 2 } & Somló Formation \\
& Lajta Limestone Formation \\
Middle Miocene & ("Leithakalk") Pécsszabolcs \\
(Lower Badenian) & Member \\
& Pusztamiske Formation Kolontár \\
& Member \\
\cline { 2 - 2 } & Hidas Formation Szentgál Member \\
\hline
\end{tabular}

Table 2

Quaternary sediments in the study area

\begin{tabular}{|l|l|}
\hline \multirow{3}{*}{ Holocene } & $\begin{array}{l}\text { fluvial deposits (alluvium in general) } \\
\text { fluvial-paludal deposits } \\
\text { fluvial-proluvial deposits } \\
\text { paludal deposits } \\
\text { proluvial deposits } \\
\text { proluvial-deluvial deposits } \\
\text { fluvial bedload } \\
\text { fluvial-deluvial deposits }\end{array}$ \\
\hline Pleistocene- & $\begin{array}{l}\text { fine-grained slope sediments } \\
\text { coarse-grained slope sediments } \\
\text { fine-grained eluvial sediments (residual weathered } \\
\text { surfaces that underwent pedogenetic } \\
\text { processes) }\end{array}$ \\
& $\begin{array}{l}\text { coarse-grained eluvial sediments (pebbly deflation } \\
\text { residues) }\end{array}$ \\
\hline
\end{tabular}

that the coast of the Early Badenian sea was located near present-day Kolontár (Darázsi-hegy/Darázsi Hill, Tik-hegy/Tik Hill); in the area east of it lagoons were located, in which brackish water species dwelt [Pirenella picta picta (Defr.), Pirenella picta melanopsiformis Auing; Baláca, Exposure KD-11 (research pit)] (Fig. 9a and b). The succession deposited in the latter environment and made up of clay, claymarl, sandy silt, calcareous clay, and bentonitic clay belongs to the Szentgál 
Fig. $9 \mathrm{a}, \mathrm{b}$

Pirenella picta picta (Defr) specimens from the southeastern part of the Baláca area (research pit, exposure KD11). Scale in $\mathrm{mm}$. Det.: J. Kókay and I. Selmeczi
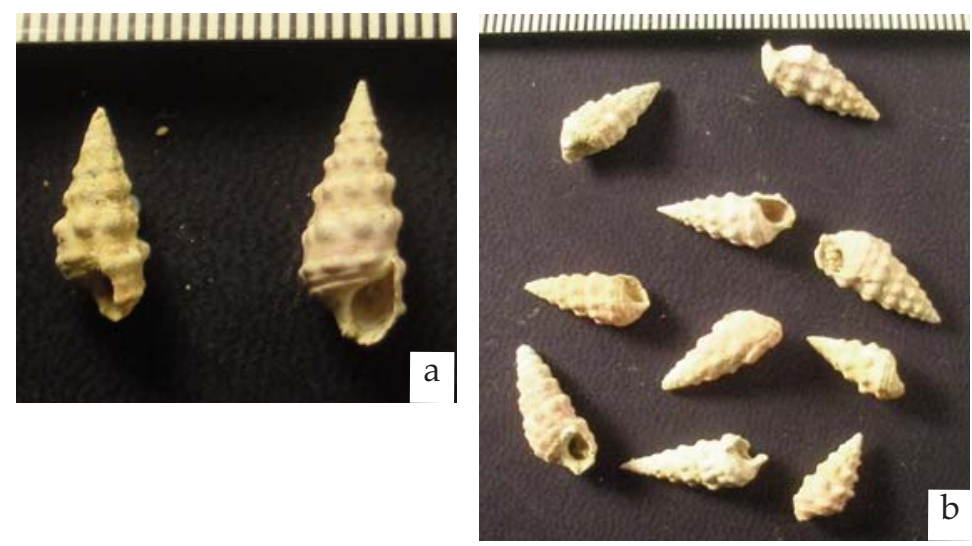

Member of the Hidas Formation. According to the data of Sütô-Szentai (2010a, b) sediments from 4.8-6.0 m and 10.0-11.0 m of borehole Kolv-1 and from 8.0-9.0 m and $9.0-11.0 \mathrm{~m}$ of borehole Kolv-2 were deposited in the early Badenian. Foraminiferal investigations were carried out by Szegó (2010a, b). The Quinqueloculina akneriana-Ammonia beccarii-Prosononion granosum association in Exposure KD-15 (research pit) indicates a warm temperate, brackish to normal saline environment, with water depth exceeding $50 \mathrm{~m}$. The association in borehole Kolv-2 $(8.0-10.0 \mathrm{~m})$ dwelt in normal-saline water, and the presence of planktonic Globigerina (one specimen) indicates the proximity to the open sea. The taxa indicate Badenian age.

The thickness of the lower Badenian succession is some tens of meters in the study area. On the basis of lithological and paleontological analogies a connection is assumed to exist between the Devecser-Kolontár sedimentary basin and the Herend Depression. The latter was the inlet of the Devecser-Kolontár Basin, and was temporarily separated from it (Kókay 1966). The characteristic some tens of meters-thick Lower Badenian succession is overlain predominantly by Pannonian (Upper Miocene) and Quaternary sediments. The lack of younger Badenian and Sarmatian formations in the study area indicates that subsidence had ended by the end of the Early Badenian.

Exposures of Upper Miocene (Pannonian) sediments, containing gravel, sand, and silty clay-marl (Kálla and Somló Formations) of a thickness of some tens of meters can be observed at the eastern rim of the Kolontár area.

\section{Quaternary deposits}

In the course of the field mapping 12 formations could be distinguished in two main facies areas (i.e. on hilltops/hillsides and in the Torna Valley), mainly on the basis of genetic aspects, also considering the age and petrologic composition of the rocks (Table 2). 
On the hilltops and hillsides slope sediments, derived from the carbonate rocks, coarse-grained and fine-grained sediments of Miocene formations, are the characteristic deposits. On the residual surfaces of plateaus on the hilltops eluvial and deluvial pebbles are sporadically accompanied by larger $(5-10 \mathrm{~cm})$, windpolished pebbles and occasionally dreikanters (Fig. 10a, b; exposures KD-30 and KD-4).

In the Torna Brook Valley the authors have distinguished several alluvial deposits (Figs 11, 12). The most spectacular exposure is located E of Kolontár, about $200 \mathrm{~m}$ from the southern reservoir (exposure KD-39), which shows the great variability of the alluvium structure.

The soils of the Torna Valley are represented predominantly by variably calcareous, slightly alkaline and neutral soils. On the hilltops and hillsides soils

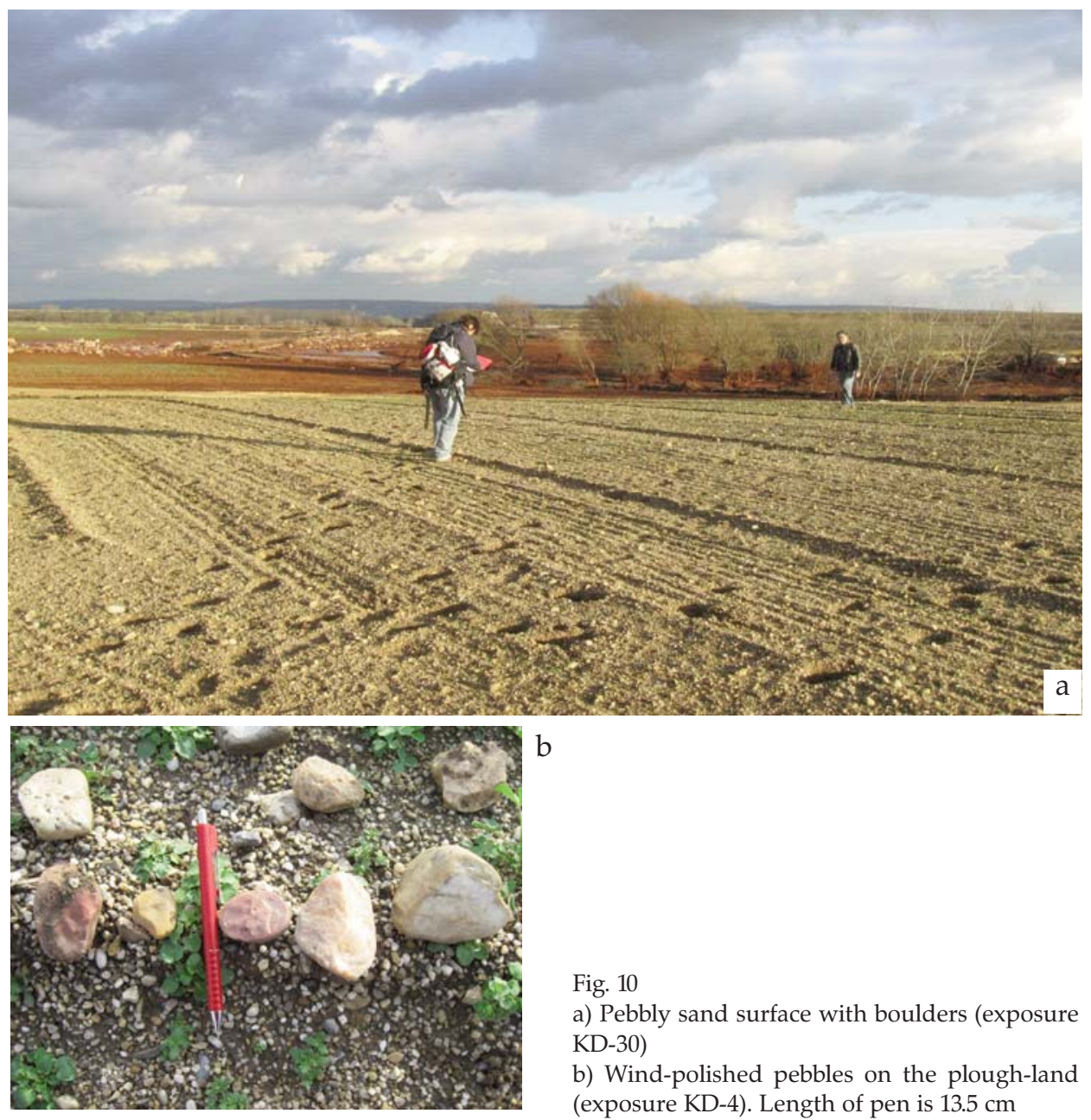




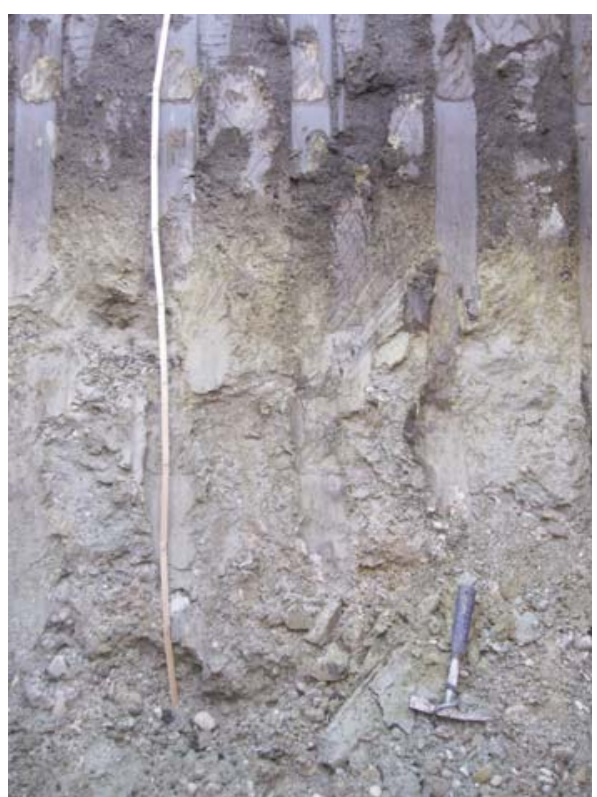

Fig. 11

Deposits E of Kolontár, about $200 \mathrm{~m}$ from the southern sludge reservoir (exposure KD-39). $0.60-1.40 \mathrm{~m}$ : humic alluvial meadow soil

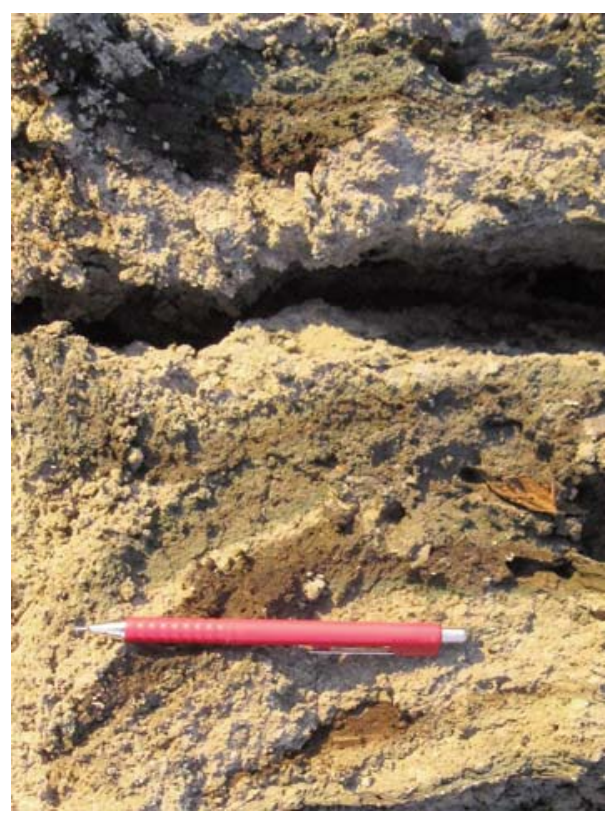

Fig. 12

Deposits E of Kolontár, about $200 \mathrm{~m}$ from the southern sludge reservoir (exposure KD-39). Below $4.3 \mathrm{~m}$ : peaty paludal clay with organicrich silt. Length of pen is $13.5 \mathrm{~cm}$

are more variable. Different type of lithosols - consisting of pebbles, rock fragments or sand - and several types of woodland soils vary in the area. Near Kolontár, in exposure KD-36, leached clay-bearing brown woodland soil can be observed.

\section{Results of the granulometric composition and carbonate content analyses}

Data in the tables, the sections of shallow drilling and the representation of granulometric composition parallel to borehole successions (Table 3; Vatai et al. 2010) give an appropriate overview of the main formations in the area.

Data derived from boreholes Kolv-4 and Kolv-6 and the geology of the area demonstrate that the Miocene succession is made up of near-shore pebbly and deeper-water, fine-grained clastic formations belonging to the Pusztamiske Formation and Hidas Formation. The latter conformably overlies the Pusztamiske Formation and the two formations may interfinger as well. The Miocene is overlain by a thin eluvial and deluvial residual weathered cover.

The upper sections of the shallow wells Kolv- 4 and Kolv-6 represent the valley and valley-slope sediments of the $1.5 \mathrm{~km}$-wide Torna Brook. These sediments 
Table 3

Data derived from sedimentological analyses of the shallow boreholes

\begin{tabular}{|c|c|c|c|c|c|c|c|}
\hline Sample & $\begin{array}{c}\text { Depth } \\
\text { (m) }\end{array}$ & Clay & Silt & Sand & Gravel & Calcite & Dolomite \\
\hline Kolv-1 & 0.4 & 4.7 & 6.1 & 87.6 & 1.2 & 0.0 & 0.0 \\
\hline Kolv-1 & 1.0 & 0.0 & 4.7 & 94.2 & 0.9 & 0.0 & 0.0 \\
\hline Kolv-1 & 1.5 & 1.2 & 1.8 & 84.7 & 0.7 & 0.0 & 0.0 \\
\hline Kolv-1 & 1.9 & 1.0 & 1.9 & 88.5 & 1.3 & 0.0 & 0.0 \\
\hline Kolv-1 & 2.6 & 29.1 & 11.4 & 18.0 & 0.0 & 30.0 & 1.0 \\
\hline Kolv-1 & 10.5 & 27.3 & 36.0 & 3.7 & 0.6 & 21.0 & 6.0 \\
\hline Kolv-2 & 0.4 & 9.6 & 22.0 & 55.7 & 5.9 & 10.0 & 0.0 \\
\hline Kolv-2 & 0.8 & 4.8 & 7.3 & 28.1 & 59.4 & 3.0 & 0.0 \\
\hline Kolv-2 & 2.3 & 15.2 & 35.1 & 32.2 & 0.0 & 18.0 & 4.0 \\
\hline Kolv-2 & 3.8 & 4.5 & 16.3 & 74.2 & 0.0 & 10.0 & 4.0 \\
\hline Kolv-2 & 5.9 & 14.7 & 50.7 & 19.8 & 0.0 & 20.0 & 9.0 \\
\hline Kolv-2 & 9.5 & 21.8 & 42.3 & 12.7 & 1.0 & 19.0 & 8.0 \\
\hline Kolv-4 & 0.1 & 6.3 & 13.0 & 61.8 & 18.6 & 0.0 & 0.0 \\
\hline Kolv-4 & 0.4 & 2.2 & 4.1 & 23.0 & 69.6 & 0.0 & 0.0 \\
\hline Kolv-4 & 2.4 & 8.6 & 18.8 & 56.0 & 8.1 & 7.0 & 0.0 \\
\hline Kolv-6 & 0.3 & 6.0 & 12.2 & 49.8 & 33.5 & 0.0 & 0.0 \\
\hline Kolv-6 & 1.3 & 2.1 & 2.1 & 26.1 & 64.7 & 0.0 & 0.0 \\
\hline Kolv-6 & 2.0 & 7.6 & 10.6 & 22.8 & 54.8 & 41.0 & 0.0 \\
\hline Kolv-6 & 3.5 & 3.2 & 6.0 & 64.1 & 25.6 & 5.0 & 0.0 \\
\hline Kolv-6 & 6.5 & 8.0 & 17.5 & 62.8 & 8.4 & 8.0 & 0.0 \\
\hline Kolv-7 & 0.4 & 4.8 & 8.7 & 49.4 & 37.4 & & \\
\hline Kolv-7 & 0.7 & 1.0 & 1.0 & 44.0 & 50.0 & & \\
\hline Kolv-8 & 0.5 & 4.6 & 9.8 & 64.6 & 19.0 & & \\
\hline
\end{tabular}

yet been exactly determined. In this area the following sediments are found: finegrained mud of flood plain facies, fluvial-paludal clayey silt rich in organic matter and pebbly-sandy bed load. On the basis of paleontological examinations the lower section of the wells belongs to the fine-grained Miocene Hidas Formation, the clay fraction of which ranges from 20 to 30 per cent.

Samples (identified as 'Dev' and characterized by the highest clay content) are from outside of the study area, from the Devecser clay pit, and represent Upper Miocene (Pannonian) clays of different types. Among them sample 'Dev-3' contains almost 50 per cent clay fraction.

On the basis of the data of some analyses the carbonate content of the Miocene formations is usually high; in some cases the carbonate content exceeds 30 per cent. Calcium carbonate is present predominantly in the form of calcite. The eluvial-deluvial sediments on the hillsides and hilltops are significantly leached; their carbonate content is zero or very low, characteristically below 1 per cent.

Comparing the carbonate content data obtained from boreholes Kolv-1 and Kolv-2, it can be seen that the calcium carbonate content of the valley sediments 
of the Torna Brook vary considerably. Based on the data of the two sections the fine-grained flood plain deposits and the fluvial-paludal sediments that contain no organic matter have no carbonate content, or their carbonate content is very low. The coarser bed loads are much richer in carbonates, predominantly in calcite.

The carbonate content of the Pannonian clay samples indicated with "Dev" ranges from 20 to 25 per cent; almost two thirds of it is associated with calcite, and one third with dolomite.

\section{Shallow section}

Geophysical and geologic cross-sections were constructed for the study area. A preliminary shallow geologic cross-section $\left(\mathrm{A}-\mathrm{A}^{\prime}\right)$ is shown in Fig. 13. The line A-A' in Fig. 7 shows the location of the geologic cross-section shown in Fig. 13.

\section{Morphology and neotectonics}

The main morphological feature of the alluvial valley is the lack of flood plain and terrace levels (see Fig. 8). Along the rim of the valley (gently sloping downstream) the alternation of different facies, such as deluvial, fluvial-deluvial, fluvial-paludal and alluvial facies, can be observed.

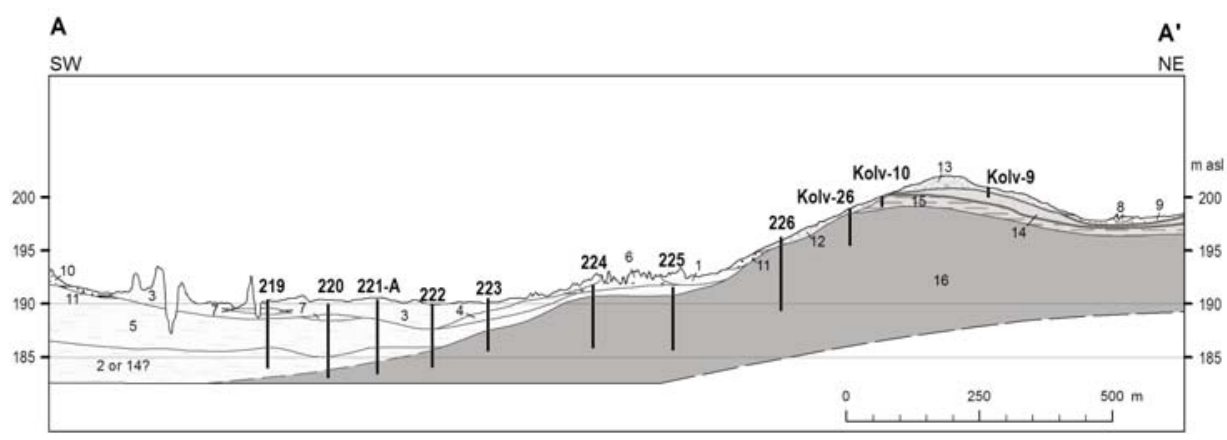

Fig. 13

SW-NE geologic cross-section across the Torna Brook. Compiled by I. Szentpétery. Legend: 1. fQ_h fluvial sediments (alluvium in general), 2. f_Qh_a fluvial clay, 3. f_Qh_klh fluvial silty sand and gravel, 4. f_Qh_h fluvial sand, 5. f_Qh_h,k fluvial sand and gravel, 6 . fb_Qh fluvial-paludal sediments, organic-rich sandy silt and silt, 7. b_Qh paludal sediments, organic-rich clay and silt, 8. p_Qh proluvial sediments: sand, gravel, and silt, 9. pd_Qh proluvial-deluvial sediments, 10. pd_Qh-h proluvialdeluvial sand, 11. fd_Qh fluvial-deluvial sediments; Upper Pleistocene-Holocene 12. d_Qp3-h finegrained deluvial sediments; sand with scattered pebbles, silt; Pleistocene, 13. eld_Qp_k,h coarsegrained eluvial sediments (pebbly deflation residues); Miocene 14. hMb_a Hidas Formation with predominance of clay, 15. pm_kMb1_al Pusztamiske Formation Kolontár Member with predominance of silt, 16. pm_kMb1_h,k Pusztamiske Formation Kolontár Member with predominance of sand and gravel; Kolv-26: section of the excavation; 223: section of the monitoring well. mBf: elevations above Baltic sea level 
The valley morphology, the roughly outlined neotectonic image, and the sedimentation features make it probable that rapid sedimentation took place simultaneously with intensive subsidence.

The damaged reservoir is located in the valley of the Torna Brook of W-E and WNW-ESE strike, near the valley head. This valley runs along the main fault of a strike-slip (transcurrent) zone. The fracture zone bends in the area of Kolontár, and a small rhombus-shaped pull-apart basin is located within the bend (Fig. 14). On the basis of the shape of the basin and its rightward-stepping geometry a dextral lateral fault is presumed. The dextral strike-slip fault character is also indicated by faults of NNE-SSW/NE-SW direction, which can be observed outside of the geometry of the basin at the northern and southern rims of the valley. These are young faults and they may have been active during the Pleistocene, since they are the determinative elements of the present-day morphology. Faults on both sides of the valley, which may have functioned as

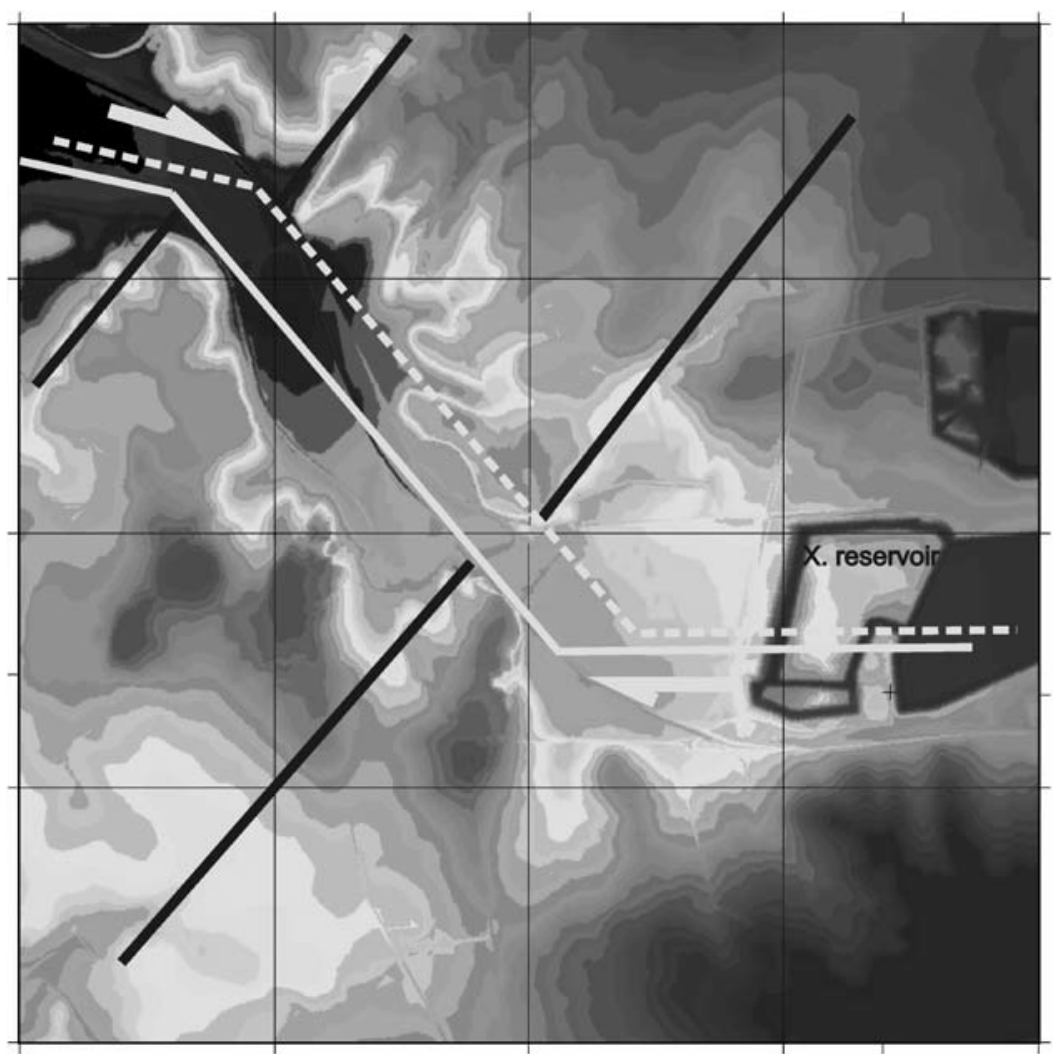

Fig. 14

Pull-apart basin in the Torna Valley: according to the neotectonic analysis a dextral displacement occurred 
normal faults, may have originally belonged together. They were probably dislocated $50-100 \mathrm{~m}$ horizontally by the dextral strike-slip displacement that took place along the valley.

Our morphologic and neotectonic interpretation, along with the lack of terraces along the valleys (namely the gradual filling up of the valley), indicates that the dextral strike-slip movement is still ongoing and that it is the youngest and most active element from a tectonic point of view. This can be indicated by the fact that there was an earthquake in the Torna Brook Valley (13 September 1953, 11:15:00; coordinates: $17.48 \mathrm{E}, 47.08 \mathrm{~N} ; \mathrm{M}=2.2$ ).

\section{Summary}

Subsequent to the red mud disaster in Kolontár the researchers of the Geological Institute of Hungary visited the area several times, and carried out field survey and reambulation mapping (Vatai et al. 2010).

An important result of the geologic mapping is that, compared to the archived data, many more Miocene and Quaternary formations have been distinguished and delineated, and could be characterized by laboratory analyses. The complicated geologic build-up of the Quaternary valley-fill sediments of the Torna Brook can be clarified by research work based on further drilling.

On the basis of the research it became clear that the valley morphology of the Torna Brook, because of a lack of the sharply separated flood plain level and terrace levels, because of the great spatial and genetic variability of valley-fill deposits, and because of the features suggesting neotectonic movements, indicates rapid sedimentation in connection with intensive subsidence in the area.

Research work based on the mapping has greatly expanded knowledge of the local geology. This knowledge can be used for engineering design in order to avoid environmental problems in the future. Data available at present are not sufficient to determine the possible geologic causes of the accident; for this, further investigation is needed.

\section{Acknowledgements}

The authors acknowledge the constructive comments of two anonymous reviewers which significantly improved the manuscript. Appreciation is also expressed to R. Barczikay-Szeiler and V. Maigut for their kind help in computer graphics and to Dr. J. Kókay and Dr. Gy. Lelkes for their help in identifying fossils.

\section{References}

Bartha, A. 2010: Jelentés a MÁFI laboratóriumi vizsgálatairól (Report on the laboratory analyses of the Geological Institute of Hungary). - Manuscript, Geological Institute of Hungary, Budapest. (In Hungarian.) 
Bence, G., B. Bernhardt, D. Bihari, Cs. Bálint, G. Császár, L. Gyalog, J. Haas., I. Horváth, Á Jámbor, M. Kaiser, J. Kéri, J. Kókay, J. Konda, Gy. Lelkesné Felvári, Gy. Majoros, Zs. Peregi, Gy. Raincsák G, Solti, Á. Tóth, Gy. Tóth. 1990: A Bakony hegység földtani képződményei. Magyarázó a Bakony hegység fedetlen földtani térképéhez (Geology of Bakony Mountains (Hungary). Explanatory book to the bedrock geological map of the Bakony Mts) 1: 50 000. - Occasional Paper of the Geological Institute of Hungary, Budapest, 119 p. (In Hungarian.)

Bihari, D. 1979a: A Bakony-hegység földtani térképe - Devecser - 1:20.000-es méretarányú földtani észlelési térkép (Geological map of the Bakony Mts - Devecser - Geological map of the Quaternary Cover, 1: 20 000). - Published by the Geological Institute of Hungary, Budapest. (In Hungarian.)

Bihari, D. 1979b: A Bakony-hegység földtani térképe - Devecser - 1:20.000-es méretarányú fedetlen földtani térkép (Geological Map of the Bakony Mts - Devecser - Bedrock geological map, 1: 20 000). - Published by the Geological Institute of Hungary, Budapest. (In Hungarian.)

Bihari, D. 1983: Devecser - Magyarázó a Bakony-hegység 20.000-es földtani térképsorozatához (Devecser - Explanatory book to the Geological map series of the Bakony Mts, 1: 20 000). Published by the Geological Institute of Hungary, 59 p. (In Hungarian.)

Császár, G., E. Csereklei, L. Gyalog eds 1985: A Bakony-hegység fedett földtani térképe. 1:50.000 (Geological Map of the Bakony Mts, Quaternary cover, 1: 50 000). - Published by the Geological Institute of Hungary, Budapest. (In Hungarian.)

Csima, K. 1975a: Nyirád. Fedetlen földtani térkép a negyedidőszaki képződmények elhagyásával, 1: 25 000. A Bakony-hegység földtani térképe, 25 000-es sorozat (Nyirád. Bedrock Geological Map, 1: 25 000. Geological map of the Bakony Mts, Map series on a scale of 1: 25 000). - Manuscript, Hungarian Geological and Geophysical Institute, Department of Geological Research, Budapest. (In Hungarian.)

Csima, K. 1975b: A nyirádi 1:25.000-es térképlap területének földtani leírása (Geology of the Nyirád map sheet, 1: 25 000). - Manuscript, Geological Institute of Hungary, Budapest. (In Hungarian.)

Csima, K., G. Solti, I. Bogáth, L. Radics 1975: Nyirád. Észlelési földtani térkép, 1: 25 000. Magyar Állami Földtani Intézet A Bakony-hegység földtani térképe, 25 000-es sorozat (Nyirád, Geological map of the Quaternary cover, Geological map of the Bakony Mts, Map series on a scale of 1: 25 000). - Manuscript, Hungarian Geological and Geophysical Institute, Department of Geological Research, Budapest. (In Hungarian.)

Darnay-Dornyai, B. 1952: Földtani felvétel a Devecser - Nyirád nevû́ 1:25.000-es méretarányú szelvényen (The results of the geological mapping in the Devecser-Nyirád map sheet on a scale of 1: 25 000). - Manuscript, Hungarian Geological and Geophysical Institute, Map Archive, Budapest. (In Hungarian.)

Dudko, A., G. Bence, I. Selmeczi 1992: Miocén medencék kialakulása a Dunántúli-középhegység DNy-i részén (The tectonic origin of Miocene basins on the south-western edge of the Transdanubian Central Range). - Annual Report of the Geological Institute of Hungary 1990, pp. 107-124. (In Hungarian with English abstract.)

Gyalog, L., G. Császár eds 1990: A Bakony-hegység fedetlen földtani térképe. 1:50. 000 (Bedrock geological map of the Bakony Mts, 1: 50 000). - Published by the Geological Institute of Hungary, Budapest. (In Hungarian.)

Hoffer, E., T. Nyitrai 1984: Jelentés a Devecseri-medence területén 1983-ban végzett szénkutató geofizikai mérésekról (Report on the geophysical measurements carried out for coal research in 1983 in the area of the Devecser basin). - Manuscript, Hungarian State Databank of Geology, Geophysics and Mining, Budapest, (Kx-127). (In Hungarian.)

Kléh, Gy. (undated): Devecser [No: 5159/3]. Magyarország Geológiai és Talajismereti térképsorozata $M=1: 25000$ (Devecser (No: 5159/3). The geological and pedological map series of Hungary, 1: 25 000). - Manuscript, Institute for Soil Sciences and Agricultural Chemistry, Centre for Agricultural Research, Hungarian Academy of Sciences, Map Archive. (In Hungarian.) 
Kókay, J. 1966: A herend-márkói barnakőszénterület földtani és ôslénytani vizsgálata (Geological and palaeontological study of the Herend-Márkó brown coal area). - Geol. Hung. Ser. Pal. Fasc. 36, 142 p., 15 plates. (In Hungarian and German with Russian abstact.)

Kovács, L. 1948: Földtani felvétel a Devecser nevú 1:25.000-es méretarányú szelvényen (The results of geological mapping in the Devecser map sheet on a scale of 1: 25 000). - Manuscript, Hungarian Geological and Geophysical Institute, Map Archive. (In Hungarian.)

Kovács, L. 1952: A Devecser és Nyirád közti harmadkori terület földtani viszonyai (Geological conditions of the Tertiary area between Devecser and Nyirád. (Conditions geologiques du terrain tertiaire située entre Devecser et Nyirád.). - Annual Report of the Geological Institute of Hungary 1948, pp. 79-83. (In Hungarian with French abstract.)

Mészáros, J. 1976a: A Bakony-hegység földtani térképe - Ajka - 1:20.000-es méretarányú földtani észlelési térkép (Geological map of the Bakony Mts - Ajka - Geological map of the Quaternary cover, 1: 20 000). - Published by the Geological Institute of Hungary, Budapest. (In Hungarian.)

Mészáros, J. 1976b: A Bakony-hegység földtani térképe - Ajka - 1:20.000-es méretarányú fedetlen földtani térkép (Geological map of the Bakony Mts - Ajka - Bedrock geological map , 1: 20 000). - Published by the Geological Institute of Hungary, Budapest. (In Hungarian.)

Mészáros, J. 1976c: A Bakony-hegység földtani térképe - Padragkút - 1:20.000-es méretarányú földtani észlelési térkép (Geological map of the Bakony Mts - Padragkút - Geological map of the Quaternary cover, 1: 20 000). - Published by the Geological Institute of Hungary, Budapest. (In Hungarian.)

Mészáros, J. 1976d: A Bakony-hegység földtani térképe - Padragkút - 1:20 000-es méretarányú fedetlen földtani térkép (Geological map of the Bakony Mts - Padragkút - Bedrock geological map , 1: 20 000). - Published by the Geological Institute of Hungary, Budapest. (In Hungarian.)

Mészáros, J. 1979: Ajka - Magyarázó a Bakony-hegység 20 000-es földtani térképsorozatához (Ajka Explanatory book to the geological map series of the Bakony Mts on a scale of 1: 20000 ). Published by the Geological Institute of Hungary, 61 p. (In Hungarian.)

Mészáros, J. 1980: Padragkút - Magyarázó a Bakony-hegység 20 000-es földtani térképsorozatához (Padragkút - Explanatory book to the geological map series of the Bakony Mts on a scale of 1 : 20 000). - Published by the Geological Institute of Hungary, 89 p. (In Hungarian.)

Mészáros, J. 1982: Nagyméretú vízszintes eltolódás a Bakony Ny-i részén és szerepe a nyersanyagkutatásban (Major horizontal tectonic dislocation as a guide to mineral prospectors in the western Bakony Mountains). - Annual Report of the Geological Institute of Hungary 1980, pp. 517-526. (In Hungarian with English abstract.)

Mészáros, J. 1983: A bakonyi vízszintes eltolódások szerkezeti és gazdaságföldtani jelentôsége (Structural and economic-geological significance of strike-slip faults in the Bakony Mountains). - Annual Report of the Geological Institute of Hungary 1981, pp. 485-502. (In Hungarian with English abstract.)

Ráner, G. 1973: Földtani alapszelvények geofizikai vizsgálata (Dabrony - Devecser - Halimba Pétervására - Fedémes) (The geophysical investigations of geological key sections (Dabrony Devecser - Halimba - Pétervására - Fedémes)). - Manuscript, Hungarian State Databank of Geology, Geophysics and Mining, Budapest, 19 p., 2 maps. (In Hungarian.)

Selmeczi, I. 2003: Prepannóniai miocén képződmények a Dunántúli-középhegység DNy-i részén (Devecser-nyirádi-medence, Tapolcai-medence, Keszthelyi-hegység É-i előtere) (Pre-Pannonian Miocene formations in the south-western part of the Transdanubian Range (Devecser-Nyirád Basin, Tapolca Basin and Northern Foreland of the Keszthely Hills)). - Manuscript, Ph.D. dissertation, University of Pécs, Faculty of Natural Sciences, 130 p. (In Hungarian.)

Síkhegyi, F. 1984: A kisalföld regionális komplex földtani vizsgálata (Regional and complex geological research of Little Hungarian Plain). - Annual Report of the Geological Institute of Hungary 1982, pp. 43-48. (In Hungarian with English abstract.)

Sütőné Szentai, M. 2010a: A Kolontár-1. sz. fúrás palynológiai vizsgálata (Palynologic investigations of borehole Kolontár-1). - Manuscript, Geological Institute of Hungary, Budapest, 3 p. (In Hungarian.) 
Sütőné Szentai, M. 2010b: A Kolontár-2. sz. fúrás palynológiai vizsgálata (Palynologic Investigations of borehole Kolontár-2. - Manuscript, Geological Institute of Hungary, Budapest, 4 p. (In Hungarian.)

Szegó, É. 2010a: Mikropaleontológiai szakvélemény a Kolontár KD-15. jelú minta foraminifera faunájáról (Micropalaeontological report on the Foraminifer fauna of sample Kolontár Kd-15). Manuscript, Geological Institute of Hungary, Budapest, 1 p. (In Hungarian.)

Szegô, É. 2010b: Szakértôi vélemény a Kolontár területén végzett kézifúrások foraminfera vizsgálatáról (Kolv-1, -2) (Expert's report on Foraminifer investigations from the Kolontár shallow drillings (Kolv-1, -2)). - Manuscript, Geological Institute of Hungary, Budapest, 2 p. (In Hungarian.)

Vatai, J., U. Fügedi, J. Kókay, L Koloszár, I. Marsi, L. Róth, M. Sütôné Szentai, É. Szegô, I. Szentpéteri, T. Szőts, Gy. Tóth 2010: Előzetes jelentés az ajkai vörösiszap-tározók környezetében végzett MÁFI munkákról (Preliminary report on the investigations carried out by the Geological Institute of Hungary in the vicinity of the red mud reservoirs of Ajka). - Manuscript, Hungarian State Databank of Geology, Geophysics and Mining, Budapest, 37 p. +14 enclosures. (In Hungarian.) 